\title{
Effects of Adrenergic Receptor Activation and Blockade on the Systolic Preejection Period, Heart Rate, and Arterial Pressure in Man*
}

\author{
Willard S. Harris, Clyde D. Schoenfeld, and Arnold M. Weissler $\ddagger$ \\ (From the Department of Medicine, The Ohio State University, Columbus, Ohio)
}

\begin{abstract}
Summary. We have investigated the possibility that alterations in the duration of the systolic preejection period can be used to estimate adrenergic influences on the human left ventricle. The preejection period was determined from high speed, simultaneous recordings of the phonocardiogram, carotid pulse tracing, and electrocardiogram. The preejection period was shortened by isoproterenol, epinephrine, and moderate doses of norepinephrine-all of which activate beta adrenergic receptors-and by cedilanid-D. It was unaltered by changes in heart rate induced by atropine and right atrial electrical pacing. Beta adrenergic receptor blockade by propranolol abolished the shortening effects of the three catecholamines but did not inhibit that due to cedilanid-D. Vasoconstriction, both alpha adrenergic (epinephrine and norepinephrine after propranolol) and nonadrenergic (angiotensin), prolonged the preejection period. Most of the shortening of the preejection period by beta adrenergic receptor activating agents and cedilanid-D and all of the prolongation accompanying pharmacologic vasoconstriction occurred after the onset of the first heart sound, thereby excluding changes in electrical-mechanical delay as a major factor in the observed preejection period responses. Shortening of the preejection period by beta adrenergic activity induced with isoproterenol was dose-related. Increasing doses of propranolol produced parallel shifts to the right in the isoproterenol dose-response curve.

In 37 normal resting subjects intravenous propranolol $(10 \mathrm{mg})$ prolonged the preejection period an average of $10(\mathrm{SE} \pm 1) \mathrm{msec}$. In six patients with psychogenic sinus tachycardia and a patient with a pheochromocytoma the presence of excessive beta adrenergic influences on the left ventricle was demonstrated by the finding of an initially short preejection period which responded with an abnormally great prolongation to beta adrenergic receptor blockade.
\end{abstract}

\section{Introduction}

The duration of the preejection period of left ventricular systole can be determined easily and

Received for publication 26 September 1966 and in revised form 5 July 1967.

Presented in part at the Annual Meeting of the American Federation for Clinical Research, Atlantic City, N. J., 1 May 1966.

Supported by grants from the Central Ohio Heart Association, the American Heart Association, and the U. S. Public Health Service (HE-6414, HE-06737, FR-34, and HE-09884). atraumatically from high speed, simultaneous recordings of the phonocardiogram, carotid pulse tracing, and electrocardiogram. As shown by Raab, De Paula e Silva, and Starcheska, epinephrine and norepinephrine shorten the systolic preejection period in man (1), reflecting the augmentation of the velocity of ventricular contraction by

$\ddagger$ Recipient of U. S. Public Health Service Career Development Award HE-K-13, 971.

Address requests for reprints to Dr. Willard S. Harris, Department of Medicine, The Ohio State University, Columbus, Ohio 43210. 
these inotropic agents (2-4). The myocardial actions of catecholamines can be abolished by beta adrenergic receptor blockade $(5,6)$. These observations suggested that one might estimate the level of beta adrenergic influences on the human left ventricle by determining the effects of the beta adrenergic receptor blocking agent, propranolol [1-isopropylamino-3-(1-naphthyloxy)-2propanol hydrochloride] $(6,7)$, on the preejection period. Before the application of such a method it was necessary to test the following hypotheses: that beta adrenergic-mediated effects on the preejection period are distinct from alpha adrenergicmediated effects, dose dependent, blocked specifically by propranolol, and independent of heart rate. The present studies were designed to test these hypotheses and to determine whether the proposed approach would actually distinguish between normal and elevated levels of endogenous beta adrenergic activity.

\section{Methods}

The 49 normal subjects were healthy male volunteers, 20 to $42 \mathrm{yr}$ old (mean age 33). 44 were inmates of the Ohio Penitentiary and five were research personnel. Studies were begun at approximately 9:00 a.m. with the subjects fasted overnight, unsedated, and supine. Cournand needles were placed in a forearm vein for drug infusions and in a brachial artery. Intra-arterial pressures were recorded with a Statham $\mathrm{P} 23 \mathrm{Db}$ strain gauge transducer placed in a plane $5 \mathrm{~cm}$ below the sternal angle. Mean pressures were obtained by electronic integration. The carotid arterial pulse was recorded externally with a funnel-shaped pick-up and an air-filled Statham P23Db transducer. The carotid pulse, phonocardiogram (Peiker microphone), and electrocardiogram were recorded simultaneously at a paper speed of $100 \mathrm{~mm} / \mathrm{sec}$ with 0.02 sec time markers (Fig. 1A). The Q-2 interval, which estimates total electromechanical systole, was measured as the interval from the beginning of the QRS complex of the electrocardiogram to the initial high frequency vibrations of the second heart sound. The duration of left ventricular ejection (left ventricular ejection time) was derived from the carotid pulse as the interval from the onset of its upstroke to the trough of the incisura. The preejection period was calculated by subtracting the left ventricular ejection time from the Q-2 interval. The preejection period is that portion of electromechanical systole which precedes the ejection period (Fig. 1B). 10 consecutive beats were analyzed and averaged for each determination. When sinus arrhythmia caused heart rate to vary more than 10 beats $/ \mathrm{min}, 20$ consecutive beats were analyzed. Heart rate was determined by dividing the average $R-R$ interval into 60 .

The preejection period of a single beat is measured to the nearest $5 \mathrm{msec}$. Because the value reported for a subject is the average of 10 or 20 beats, the last digit of this value may be any numeral from 0 to 9 . With care, recordings can be obtained showing a sharp delineation of the four landmarks used to determine the preejection period: onset of the $Q$ wave, carotid upstroke and second heart sound, and trough of the carotid incisura. In a normal subject with regular sinus rhythm, recordings of consecutive series of 10 successive beats each yield averages for the preejection period which do not vary among series by more than $5-10$ msec. Within each series the beat-to-beat variation is less than $10 \mathrm{msec}$. The technique has enhanced validity for pharmacological studies, such as the present one, in which each subject is his own control. In such studies it is essential that the records from both the control and experimental periods be read in exactly the same way.

The tracings of 20 subjects were analyzed further to determine the effects of various pharmacologic agents on the duration of the QRS complex and two subdivisions of the preejection period: the Q-1 interval (measured from the onset of the QRS complex to the initial high frequency component of the first heart sound) and the interval between the first heart sound and the onset of ejection (calculated by subtracting the Q-1 interval from the preejection period).

The initial series of studies attempted to delineate the effects on the preejection period of pharmacologic agents producing activation and blockade of beta adrenergic receptors, activation of alpha adrenergic receptors, and nonadrenergic vasoconstriction. In these studies isoproterenol hydrochloride was infused intravenously at $2.5 \mu \mathrm{g} / \mathrm{min}$, epinephrine hydrochloride at $5 \mu \mathrm{g} / \mathrm{min}$, $l$-norepinephrine bitartrate at $7.5,15$, and $22.5 \mu \mathrm{g} \mathrm{min}$, and angiotensin amide at $2.5 \mu \mathrm{g} / \mathrm{min}$. The dose of norepinephrine is expressed as the base; for all other drugs, doses are given in terms of the salt. Normal saline was the diluent for all agents and was infused as a placebo. Separate infusions of isoproterenol and one other drug (epinephrine, norepinephrine, or angiotensin) were given to 25 subjects before and after beta adrenergic receptor blockade by $10 \mathrm{mg}$ of intravenous propranolol hydrochloride. ${ }^{1} 11$ additional subjects received isoproterenol alone without beta adrenergic receptor blockade. Control observations on heart rate, preejection period, and intra-arterial pressure were made at the start of each study, before and after propranolol, and at the end of the study. The following is a typical experimental sequence: control, isoproterenol, three dose-levels of norepinephrine, control, propranolol administration, propranolol control, isoproterenol, three dose-levels of norepinephrine, propranolol control. Propranolol was injected intravenously over a 5-10 min period. All other agents were administered intravenously at a constant rate by a motor-driven pump (Harvard Apparatus Co., Inc., Dover, Mass.). The total volume of fluid for these infusions was less than $50 \mathrm{ml}$. Data collection was begun during the 4th $\min$ of infusion of isoproterenol and epi-

\footnotetext{
1 Propranolol hydrochloride was generously provided by Dr. Alex Sahagian-Edwards, Ayerst Laboratories, New York, N. Y.
} 
A

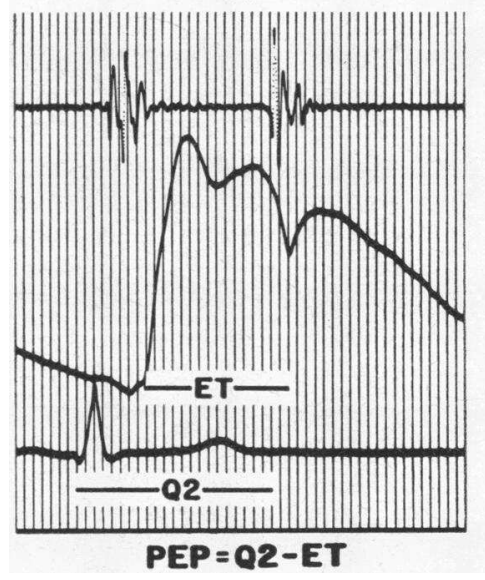

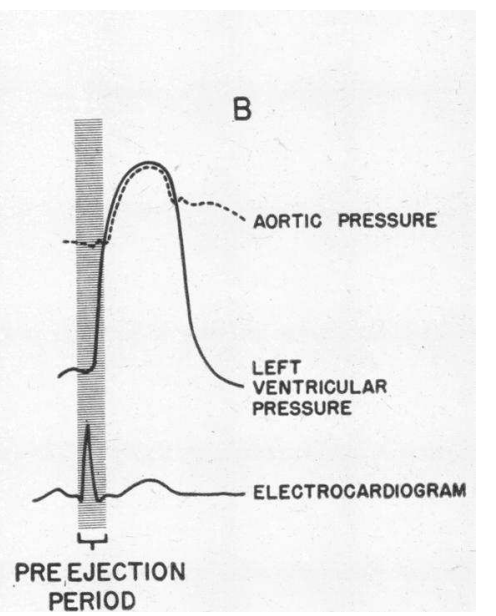

Fig. 1. A, Derivation of the preejection period. Simultaneous phonocardiogram, carotid pulse tracing, and electrocardiogram. ET, ejection time; Q2, Q-2 interval; PEP, preejection period. Paper speed $100 \mathrm{~mm}$ per second. Time lines $0.02 \mathrm{sec}$.

B, Schematic Representation of the preejection period. It extends from the beginning of the $Q$ wave of the electrocardiogram to the opening of the aortic valve.

nephrine and the 6th min of norepinephrine and angiotensin. The end of each infusion, including that of propranolol, was followed by a $15-20$ min stabilization period before the next drug infusion was begun.

Another series of studies were performed to evaluate the effects on the preejection period of changes in heart rate and of graded doses of isoproterenol. In two normal subjects the responses of the preejection period were determined during changes in heart rate produced by electrical stimulation of the right atrium at various rates up to 126-142 beats/minute. This was accomplished by using a Teflon-coated, platinum-tipped, stainless steel wire catheter $(8),{ }^{2}$ inserted percutaneously via an antecubital vein, and a 2.5-5 ma direct current stimulus of 2 msec duration. In six subjects the preejection period was determined every $10-15 \mathrm{~min}$ for $30 \mathrm{~min}$ before and $2.5 \mathrm{hr}$ after the rapid $(5 \mathrm{sec})$ intravenous injection of $2 \mathrm{mg}$ of atropine sulfate, an agent which produces nonadrenergic cardioacceleration (9). On a 2nd day, the same $3 \mathrm{hr}$ study was repeated in three of these subjects except that $5 \mathrm{ml}$ of saline was injected instead of atropine. On a 3rd day each of these three subjects was studied with graded doses of isoproterenol $(0.625,1.25$, and $2.5 \mu \mathrm{g} / \mathrm{min}$ ).

Additional studies were done to determine whether propranolol would alter the responses of the preejection period to a nonadrenergic inotropic agent, such as a digitalis glycoside (10). In five normal subjects, the preejection period was determined every 10-20 min for $30 \mathrm{~min}$ before and $2 \mathrm{hr}$ after the intravenous injection of $1.2 \mathrm{mg}$ of cedilanid-D. 4 months later these studies were repeated in the same subjects with the preejection period

\footnotetext{
2 Davis \& Geck Division, American Cyanamid Co., Danbury, Conn.
}

determined for $30 \mathrm{~min}$ before and $30 \mathrm{~min}$ after the intravenous infusion of $10 \mathrm{mg}$ of propranolol and then for $2 \mathrm{hr}$ after the intravenous injection of $1.2 \mathrm{mg}$ of cedilanid-D.

The responses of the preejection period were used to test for competitive antagonism between isoproterenol and propranolol in one normal subject. The effects of propranolol on the isoproterenol dose-response curve were determined in this subject on 4 different days. Each day he received graded doses of intravenous isoproterenol preceded either by a saline placebo or by $2.5,5$, or $10 \mathrm{mg}$ of intravenous propranolol.

Studies were performed in patients suspected of having excessive cardiac beta adrenergic activity. In six psychotic patients with persistent sinus tachycardia and one patient with a pheochromocytoma, secreting epinephrine and norepinephrine (as evidenced by elevated urinary excretion of epinephrine, norepinephrine, metanephrine, and normetanephrine), the duration of the preejection period was determined immediately before and after beta adrenergic blockade. The psychotic patients were afebrile, euthyroid by laboratory tests, free of organic heart disease, and off all medication. After propranolol caused cardiac slowing three of the psychotic patients were given an intravenous injection of $2 \mathrm{mg}$ of atropine in order to restore their heart rates to prepropranolol levels. Probabilities were calculated with the paired $t$ test (11).

\section{Results}

The average preejection period in the 49 normal subjects was 105 ( $\mathrm{sE} \pm 2)$ msec. The control data before and after $10 \mathrm{mg}$ of intravenous propranolol are presented in Table I. In normal basal subjects propranolol lengthened the preejection 
TABLE I

Effects of propranolol in 37 normal subjects*

\begin{tabular}{|c|c|c|c|c|c|c|c|c|c|c|}
\hline & & & & & & & \multicolumn{4}{|c|}{ Brachial artery pressure } \\
\hline & \multicolumn{3}{|c|}{ Preejection period } & \multicolumn{3}{|c|}{ Heart rate } & \multicolumn{2}{|c|}{ Systolic/diastolic } & \multicolumn{2}{|c|}{ Mean } \\
\hline & B & $\mathbf{A}$ & $\Delta$ & B & $\mathbf{A}$ & $\Delta$ & B & A & B & A \\
\hline & \multicolumn{3}{|c|}{ msec } & \multicolumn{3}{|c|}{ beats/min } & \multicolumn{4}{|c|}{$m m \mathrm{Hg}$} \\
\hline $\begin{array}{l}\text { Mean } \\
\text { SE } \\
P\end{array}$ & $\begin{array}{l}105 \\
\pm 2\end{array}$ & $\begin{array}{l}115 \\
\pm 2\end{array}$ & $\begin{array}{c}+10 \\
\pm 1 \\
<0.001\end{array}$ & $\begin{array}{r}69 \\
\pm 2\end{array}$ & $\begin{array}{r}63 \\
\pm 1\end{array}$ & $\begin{array}{c}-6 \\
\pm 1 \\
<0.001\end{array}$ & $\begin{array}{l}117 / 65 \\
\pm 2 / \pm 1\end{array}$ & $\begin{array}{l}109 / 65 \\
\pm 2 / \pm 2\end{array}$ & $\begin{array}{r}84 \\
\pm 1\end{array}$ & $\begin{array}{r}84 \\
\pm 2\end{array}$ \\
\hline
\end{tabular}

${ }^{*} \mathrm{~B}$, before propranolol; A, after $10 \mathrm{mg}$ intravenous propranolol; $\Delta$, difference between A and B. Average age of subjects is $33 \mathrm{yr}$ (range 20-42 $\mathrm{yr}$ ). Average body surface area is $1.89 \mathrm{~m}^{2}$ (range $1.48-2.21 \mathrm{~m}^{2}$ ).

period an average of $10(\mathrm{SE} \pm 1) \mathrm{msec}$ (range 1$23 \mathrm{msec}$ ). Responses before the administration of propranolol are measured from prepropranolol control levels, those after propranolol are measured from postpropranolol control levels. Isoproterenol shortened the preejection period an average of $36 \mathrm{msec}$ before propranolol and $4 \mathrm{msec}$ after propranolol $(P<0.001$, Table II). Isoproterenol did not alter the duration of the QRS complex. Epinephrine shortened the preejection period an average of $30 \mathrm{msec}$ before propranolol but lengthened it $15 \mathrm{msec}$ after propranolol (Table II). Before propranolol administration norepinephrine prolonged the preejection period an aver- age of $5 \mathrm{msec}$ at $7.5 \mu \mathrm{g} / \mathrm{min}$ but shortened it 8 $\mathrm{msec}$ at $15 \mu \mathrm{g} / \mathrm{min}$ and $9 \mathrm{msec}$ at $22.5 \mu \mathrm{g} / \mathrm{min}$. After propranolol, all three doses of norepinephrine prolonged the preejection period: 16,21 , and $26 \mathrm{msec}$, respectively (Table III). Angiotensin lengthened the preejection period an average of $18 \mathrm{msec}$ before and $23 \mathrm{msec}$ after propranolol (Table II). Cedilanid-D shortened the preejection period an average of $17 \mathrm{msec}$ before and $24 \mathrm{msec}$ after propranolol (Table IV). In the 20 subjects whose preejection subdivisions were analyzed further, a decrease in the interval between the first heart sound and the onset of ejection accounted for averages of 74,81 , and $76 \%$ of the shortening

TABLE II

Effects of isoproterenol, epinephrine, and angiotensin*

\begin{tabular}{|c|c|c|c|c|c|c|c|c|}
\hline & \multirow{2}{*}{\multicolumn{2}{|c|}{$\stackrel{\Delta}{\text { Preejection period }}$}} & \multirow{2}{*}{\multicolumn{2}{|c|}{$\underset{\text { Heart rate }}{\Delta}$}} & \multicolumn{4}{|c|}{$\underset{\text { Brachial artery pressure }}{\Delta}$} \\
\hline & & & & & \multicolumn{2}{|c|}{ Systolic/diastolic } & \multicolumn{2}{|c|}{ Mean } \\
\hline & B & A & B & A & B & A & B & A \\
\hline & \multicolumn{2}{|c|}{ msec } & \multicolumn{2}{|c|}{ beats/min } & & $m m \mathrm{Hg}$ & & \\
\hline \multicolumn{9}{|c|}{ Changes due to isoproterenol $(n=36)$} \\
\hline $\begin{array}{l}\text { Mean } \\
\text { SE } \\
P\end{array}$ & $\begin{array}{l}-36 \\
\pm 2 \\
<0.001\end{array}$ & $\begin{array}{l}-4 \\
\pm 1 \\
<0.001\end{array}$ & $\begin{array}{l}\text { Group I } \\
\quad+23 \\
\pm 2 \\
<0.001\end{array}$ & $\begin{array}{l}\text { Before a } \\
+1 \\
\pm 1 \\
\text { NS }\end{array}$ & $\begin{array}{c}\text { fter propranolol } \\
+23 /-7 \\
\pm 2 / \pm 1 \\
<0.001 /<0.001\end{array}$ & $\begin{array}{l}=25) \\
\quad+1 /-1 \\
\quad \pm 1 / \pm 1 \\
\text { NS/NS }\end{array}$ & $\begin{array}{c}-3 \\
\pm 1 \\
<0.025\end{array}$ & $\begin{array}{l}\quad 0 \\
\pm \quad 1 \\
\text { NS }\end{array}$ \\
\hline $\begin{array}{l}\text { Mean } \\
\text { SE } \\
P\end{array}$ & $\begin{array}{l}-45 \\
\pm 2 \\
<0.001\end{array}$ & & $\begin{aligned} & \text { Gro } \\
&+ 23 \\
& \pm 2 \\
&<0.001\end{aligned}$ & II. Bef & $\begin{array}{c}\text { propranolol }(n= \\
+19 /-7 \\
\pm 4 / \pm 1 \\
<0.001 /<0.001\end{array}$ & & & $\begin{array}{r}-2 \\
\pm 1 \\
<0.05\end{array}$ \\
\hline \multicolumn{9}{|c|}{ Changes due to epinephrine $(n=10)$} \\
\hline $\begin{array}{l}\text { Mean } \\
\mathrm{SE} \\
P\end{array}$ & $\begin{array}{l}-30 \\
\pm 2 \\
<0.001\end{array}$ & $\begin{array}{l}+15 \\
\pm 2 \\
<0.001\end{array}$ & $\begin{array}{l}+11 \\
\pm 3 \\
<0.01\end{array}$ & $\begin{array}{l}-10 \\
\pm 1 \\
<0.001\end{array}$ & $\begin{array}{c}+6 /-6 \\
\pm 1 / \pm 1 \\
<0.005 /<0.005\end{array}$ & $\begin{array}{c}+21 /+12 \\
\pm 3 / \pm 2 \\
<0.001 /<0.001\end{array}$ & $\begin{array}{l}-4 \\
\pm 2 \\
<0.05\end{array}$ & $\begin{array}{l}+15 \\
\pm 2 \\
<0.001\end{array}$ \\
\hline \multicolumn{9}{|c|}{ Changes due to angiotensin $(n=5)$} \\
\hline $\begin{array}{l}\text { Mean } \\
\text { SE }\end{array}$ & $\begin{array}{l}+18 \\
\pm 2\end{array}$ & $\begin{array}{l}+23 \\
\pm 3\end{array}$ & $\begin{array}{l}-14 \\
\pm 5\end{array}$ & $\begin{array}{l}-4 \\
\pm 3\end{array}$ & $\begin{array}{l}+42 /+26 \\
\pm 6 / \pm 2\end{array}$ & $\begin{array}{l}+40 /+26 \\
\pm 5 / \pm 2\end{array}$ & $\begin{array}{l}+33 \\
\pm 2\end{array}$ & $\begin{array}{l}+31 \\
\pm 3\end{array}$ \\
\hline
\end{tabular}

${ }^{*} \mathrm{~B}$, before propranolol; $\mathrm{A}$, after $10 \mathrm{mg}$ intravenous propranolol; $\Delta$, difference between the experimental period and the prepropranolol or postpropranolol control period; NS, not significant. 
TABLE III

Effects of norepinephrine

\begin{tabular}{|c|c|c|c|c|c|c|c|c|c|c|c|c|}
\hline & \multicolumn{6}{|c|}{$\stackrel{\Delta}{\text { Preejection period }}$} & \multicolumn{6}{|c|}{$\underset{\text { Heart rate }}{\Delta}$} \\
\hline & \multicolumn{3}{|c|}{ Before propranolol } & \multicolumn{3}{|c|}{ After propranolol } & \multicolumn{3}{|c|}{ Before propranolol } & \multicolumn{3}{|c|}{ After propranolol } \\
\hline & \multicolumn{6}{|c|}{ msec } & \multicolumn{6}{|c|}{ beats/min } \\
\hline Dose + & 7.5 & 15 & 22.5 & 7.5 & 15 & 22.5 & 7.5 & 15 & 22.5 & 7.5 & 15 & 22.5 \\
\hline Mean & +5 & -8 & -9 & +16 & +21 & +26 & -12 & -17 & -25 & -12 & -20 & -27 \\
\hline SE & \pm 2 & \pm 2 & & \pm 3 & \pm 3 & & \pm 2 & \pm 2 & \pm 2 & \pm 1 & \pm 1 & \\
\hline$P$ & $<0.05$ & $<0.01$ & & $<0.001$ & $<0.001$ & & $<0.001$ & $<0.001$ & $<0.001$ & $<0.001$ & $<0.001$ & \\
\hline
\end{tabular}

* The $\Delta$ is the difference between the norepinephrine period and the prepropranolol or postpropranolol control period. The $P$ values refer to this $\Delta$. ceived an additional dose of $22.5 \mu \mathrm{g} / \mathrm{min}$.

of the preejection period produced by isoproterenol, epinephrine, and cedilanid-D, respectively (Table V). All the prolongation of the preejection period induced by epinephrine after propranolol, norepinephrine after propranolol, and angiotensin occurred after the onset of the first heart sound.

It is noteworthy that in addition to its effects on the preejection period propranolol slowed the control heart rate in normal subjects an average of $6(\mathrm{sE} \pm 1)$ beats/min $(P<0.001)$ without affecting arterial mean or diastolic pressure. Propranolol abolished all the responses to isoproterenol, including its increase of heart rate and arterial systolic pressure and its reduction of arterial diastolic and mean pressure. The same dose of propranolol has been shown previously to suppress almost completely the effects of isoproterenol (2.5 $\mu \mathrm{g} / \mathrm{min}$ ) on cardiac output and systemic vascular resistance (12). Hence, the dose of propranolol employed was adequate to block the cardiac and peripheral arterial beta adrenergic receptors. As would be expected from the unmasking of its alpha adrenergic (vasoconstrictive) properties by beta adrenergic receptor blockade (12), epinephrine after propranolol exhibited a pressor effect accompanied by reflex bradycardia. The prepropranolol bradycrotic and pressor responses to norepinephrine were unaltered by beta adrenergic receptor blockade.

In each of three subjects who received a saline placebo but no drugs the preejection period did not vary more than $5 \mathrm{msec}$ above or below the subject's mean value during a $3 \mathrm{hr}$ observation period. The effects on the preejection period of cardioacceleration by atropine and right atrial electrical pacing are compared to those during isoproterenol infusion in Fig. 2. After injection of atropine the heart rate rose from an average baseline of 68 beats/min to an average maximum of 104 beats/ min and then declined gradually over the next several hours. Neither atropine nor right atrial electrical pacing shortened the preejection period despite cardioacceleration up to levels of 128 (atropine) and 142 (pacing) beats/min. In contrast, graded infusions of isoproterenol shortened the pre-ejection period in a dose-related manner (Fig. 3 ) while modestly augmenting heart rate (Fig. 2). In the one patient tested, pretreatment with increasing doses of propranolol produced parallel shifts of the isoproterenol dose-response curve to the right (Fig. 4).

The psychotic patients with tachycardia had short preejection periods, averaging 88 ( $\mathrm{SE} \pm 4$ ) msec (Table VI). Propranolol administration prolonged these an average of $30 \mathrm{msec}$, or $34 \%$ (three times the normal mean response), while slowing the heart rate an average of 27 beats/min but not affecting arterial pressure significantly. After propranolol the injection of atropine in three psychotic patients returned their heart rates nearly to the prepropranolol level without affecting the preejection period. The patient with a pheochromocytoma had a short preejection period (69 msec) which beta adrenergic receptor blockade prolonged $23 \mathrm{msec}$, or $33 \%$.

\section{Discussion}

The preejection period encompasses the time required for ventricular electrical activation, electrical-mechanical coupling, and the rise of left ventricular pressure from ventricular end-diastolic to aortic-diastolic levels. The shortening of the preejection period induced by isoproterenol, epi- 
TABLE III

in 12 normal subjects*

\begin{tabular}{|c|c|c|c|c|c|c|c|c|c|c|c|}
\hline \multicolumn{12}{|c|}{$\underset{\text { Brachial artery pressure }}{\Delta}$} \\
\hline \multicolumn{6}{|c|}{ Systolic/diastolic } & \multicolumn{6}{|c|}{ Mean } \\
\hline \multicolumn{3}{|c|}{ Before propranolol } & \multicolumn{3}{|c|}{ After propranolol } & \multicolumn{3}{|c|}{ Before propranolol } & \multicolumn{3}{|c|}{ After propranolol } \\
\hline $\begin{array}{c}7.5 \\
+30 /+15 \\
\pm 3 / \pm 2 \\
<0.001 /<0.001\end{array}$ & $\begin{array}{c}15 \\
+52 /+17 \\
\pm 3 / \pm 2 \\
<0.001 /<0.001\end{array}$ & $\begin{array}{c}22.5 \\
+63 /+20\end{array}$ & $\begin{array}{c}7.5 \\
+28 /+16 \\
\pm 4 / \pm 2 \\
<0.001 /<0.001\end{array}$ & $\begin{array}{c}m m \mathrm{Hg} \\
15 \\
+54 /+24 \\
\pm 5 / \pm 2 \\
<0.001 /<0.001\end{array}$ & $\begin{array}{c}22.5 \\
+78 /+33\end{array}$ & $\begin{array}{c}7.5 \\
+21 \\
\pm 2 \\
<0.001\end{array}$ & $\begin{array}{r}15 \\
+29 \\
\pm 2 \\
<0.001\end{array}$ & $\begin{array}{l}22.5 \\
+35\end{array}$ & $\begin{array}{c}7.5 \\
+20 \\
\pm 2 \\
<0.001\end{array}$ & $\begin{array}{c}15 \\
+32 \\
\pm 3 \\
<0.001\end{array}$ & $\begin{array}{l}22.5 \\
+41\end{array}$ \\
\hline
\end{tabular}

nephrine, and cedilanid-D occurs largely between the onset of the first heart sound and the beginning of ejection, an interval which takes place entirely during left ventricular isovolumic contraction. The duration of isovolumic contraction is inversely related to the rate of rise of left ventricular pressure (13). Since positive inotropic interventions accelerate this rate of rise (13), it would appear most appropriate to use the interval between the first heart sound and the beginning of left ventricular ejection in the detection of these inotropic influences. However, the onset of the first heart sound is often difficult to determine and its relation to intracardiac pressure events is considerably altered by the very inotropic interventions which shorten the preejection period (14). For these reasons, the total preejection period is more reliable than either of its subdivisions as an indicator of these inotropic influences on left ventricular contraction before ejection. In addition

TABLE IV

Effects of cedilanid-D*

\begin{tabular}{|c|c|c|c|c|}
\hline & \multicolumn{2}{|c|}{$\stackrel{\Delta}{\text { Preejection period }}$} & \multicolumn{2}{|c|}{$\stackrel{\Delta}{\text { Heart rate }}$} \\
\hline & $\mathrm{B} \ddagger$ & A\& & B $¥$ & $A \&$ \\
\hline & \multicolumn{2}{|c|}{ msec } & \multicolumn{2}{|c|}{ beats/min } \\
\hline $\begin{array}{l}\text { Mean } \\
\text { SE }\end{array}$ & $\begin{array}{l}-17 \\
\pm 1\end{array}$ & $\begin{array}{l}-24 \\
\pm 4\end{array}$ & $\begin{array}{l}-9 \\
\pm 3\end{array}$ & $\begin{array}{l}-3 \\
\pm 3\end{array}$ \\
\hline
\end{tabular}

* The values for cedilanid-D were determined $60 \mathrm{~min}$ after the midpoint of a 3 min intravenous injection of 1.2 mg cedilanid-D.

$\ddagger \mathrm{B}, \Delta$ due to cedilanid-D before propranolol. This was calculated as the mean of the four control determinations minus the subsequent 60 min cedilanid-D value.

$\S \mathrm{A}, \Delta$ due to cedilanid-D after propranolol. This was calculated as the postpropranolol control value obtained $30 \mathrm{~min}$ after the intravenous injection of $10 \mathrm{mg}$ propranolol minus the subsequent $60 \mathrm{~min}$ cedilanid-D value. to their positive inotropic actions, peripheral vasodilatation by isoproterenol and epinephrine, through its lowering of aortic diastolic pressure, may also contribute to the shortening of the preejection period induced by these agents.

The effects of catecholamines on the preejection period are conveniently discussed in terms of the dual adrenergic receptor hypothesis $(15,16)$. Activation of beta adrenergic receptors causes cardiostimulation and vasodilatation while activation of alpha adrenergic receptors produces vasoconstriction (16). In the present study isoproterenol, epinephrine, and norepinephrine, which activate beta adrenergic receptors, shortened the preejection period, confirming the earlier observations of Raab and his associates (1). These effects of isoproterenol and epinephrine cannot be attributed to cardioacceleration since the present results with atropine and right atrial pacing would indicate that changes in heart rate do not, by themselves, alter the preejection period in man. In the present study shortening of the preejection

TABLE V

Per cent of the preejection period response occurring after the first heart sound

\begin{tabular}{|c|c|c|c|}
\hline \multirow[b]{2}{*}{ Drug } & \multirow{2}{*}{$\begin{array}{l}\text { No. of - } \\
\text { sub- } \\
\text { jects }\end{array}$} & \multicolumn{2}{|c|}{$\frac{\Delta \text { Preejection period }-\Delta Q-1 \text { interval }}{\Delta \text { Preejection period }} \times 100$} \\
\hline & & $\begin{array}{c}\text { Before } \\
\text { propranolol }\end{array}$ & $\begin{array}{c}\text { After } \\
\text { propranolol }\end{array}$ \\
\hline $\begin{array}{l}\text { Isoproterenol } \\
\text { Epinephrine } \\
\text { Norepinephrine* } \\
\text { Angiotensin } \\
\text { Cedilanid-D } \\
\text { Propranolol }\end{array}$ & $\begin{array}{r}10 \\
* \quad 5 \\
5 \\
5 \\
5 \\
15\end{array}$ & $\begin{array}{r}74 \\
81 \\
\\
100 \\
76 \\
80\end{array}$ & $\begin{array}{r}100 \\
100 \\
100 \\
79\end{array}$ \\
\hline
\end{tabular}

* Dose of norepinephrine, $15 \mu \mathrm{g} / \mathrm{min}$. The effects of norepinephrine before propranolol on the preejection period (average, $12 \mathrm{msec}$ ) and the $Q-1$ interval (average, $3 \mathrm{msec}$ ) were not large enough to permit a valid estimate of this per cent. 


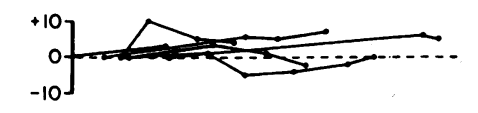

ATROPINE $n=6$

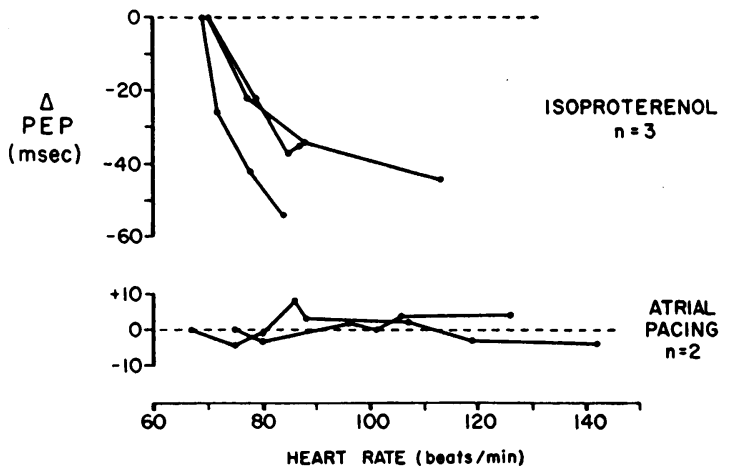

Fig. 2. EFFECTS ON PREEJECTION PERIOD OF CARdioACCELERATION BY ATROPINE, ISOPROTERENOL, AND RIGHT ATRIAL PACING. Each curve presents data from a normal subject. Three of the six subjects who received atropine (top panel) were restudied on another day with graded infusions of isoproterenol (middle panel).

period was greatest with isoproterenol, a drug with virtually pure beta adrenergic receptor activating properties (16) (Fig. 5). It was intermediate with epinephrine, a drug with predominant beta adrenergic but also considerable alpha adrenergic properties (16). It was least with norepinephrine, a drug with potent cardiac beta adrenergic receptor activating properties (16), but one which in man is more vasoconstrictive and pressor than is epinephrine (17). Thus, the degree of shortening by these three agents appears to be related directly to their cardiac and vascular beta adrenergic effects and inversely to their alpha

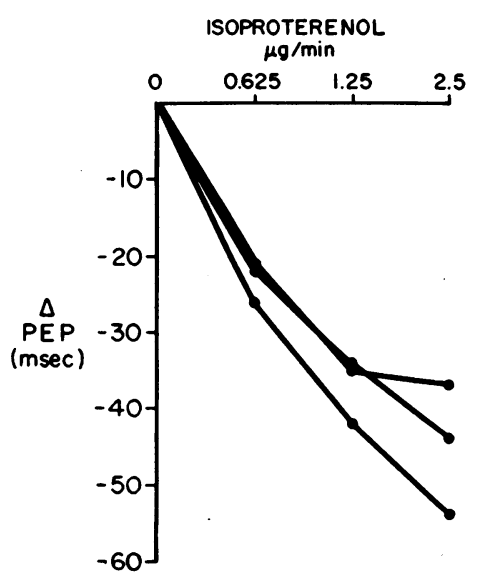

FIG. 3. DOSE-RESPONSE CURVES FOR ISOPROTERENOL IN THREE NORMAL SUBJECTS. adrenergic, or vasoconstrictive, effects. The modifying influence of alpha adrenergic activation on the duration of the preejection period is suggested further by the effects of these three catecholamines after beta adrenergic receptor blockade. After propranolol, isoproterenol had very little effect while epinephrine and norepinephrine actually prolonged the preejection period. This new effect of epinephrine and norepinephrine, which emerges during beta adrenergic blockade, is presumably due to the residual alpha adrenergic receptor stimulating, or vasoconstrictive, properties

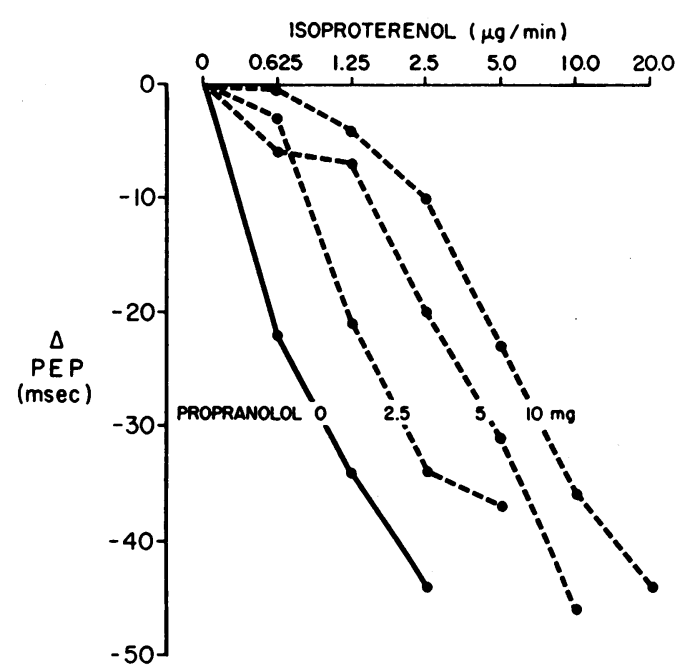

Fig. 4. EFFECTS OF PROPRANOLOL ON DOSE-RESPONSE CURVE FOR ISOPROTERENOL IN A NORMAL SUBJECT. Each curve was obtained on a separate day. The first curve (solid line) was obtained after a placebo, the second after $2.5 \mathrm{mg}$ of intravenous propranolol, and the next two after 5 and $10 \mathrm{mg}$ of intravenous propranolol, respectively. Increasing doses of propranolol shift the isoproterenol dose-response curve in parallel fashion to the right.

of these two agents (12). This concept is supported by the observation that angiotensin, a nonadrenergic vasoconstricting agent, lengthened the preejection period both before and after propranolol. Thus vasoconstriction, both alpha adrenergic and nonadrenergic, prolongs the preejection period. In contrast, beta adrenergic activity is characterized by a shortening of the preejection period, an effect which propranolol blocks. The prolongation of the preejection period accompanying the administration of norepinephrine after propranolol or angiotensin has recently been shown to be absent after cholinergic receptor blockade with 
TABLE VI

Effects of beta receptor blockade in patients suspected of having excessive beta adrenergic activity*

\begin{tabular}{|c|c|c|c|c|c|c|c|c|c|c|c|c|c|c|c|c|}
\hline & & & & & & & & & \multicolumn{8}{|c|}{ Brachial artery pressure } \\
\hline & \multicolumn{4}{|c|}{ Preejection period } & \multicolumn{4}{|c|}{ Heart rate } & \multicolumn{4}{|c|}{ Systolic/diastolic } & \multicolumn{4}{|c|}{ Mean } \\
\hline & B & A & $\Delta$ & Atr & B & A & $\Delta$ & Atr & B & A & $\Delta$ & Atr & B & $\mathbf{A}$ & $\Delta$ & Atr \\
\hline & \multicolumn{4}{|c|}{$m s e c$} & \multicolumn{4}{|c|}{ beats/min } & \multicolumn{8}{|c|}{$m m \mathrm{Hg}$} \\
\hline \multicolumn{17}{|c|}{ Six psycholic patients with sinus tachycardia } \\
\hline Mean & 88 & 118 & +30 & 120 & 109 & 81 & -27 & 99 & $131 / 78$ & $125 / 77$ & $-6 /-1$ & $122 / 81$ & 98 & 96 & -2 & 98 \\
\hline & \pm 4 & \pm 5 & $\begin{array}{c} \pm 2 \\
<0.001\end{array}$ & & \pm 4 & \pm 3 & $\begin{array}{c} \pm 2 \\
<0.001\end{array}$ & & $\pm 3 / \pm 3$ & $\pm 3 / \pm 3$ & $\begin{array}{l} \pm 3 / \pm 2 \\
\text { NS/NS }\end{array}$ & & \pm 3 & \pm 3 & $\begin{array}{l} \pm 2 \\
\mathrm{NS}\end{array}$ & \\
\hline \multicolumn{17}{|c|}{ Patient with pheochromocytoma 8} \\
\hline & 69 & 92 & +23 & & 102 & 77 & -25 & & $222 / 95$ & 214/106 & $-8 /+11$ & & 146 & 152 & +6 & \\
\hline
\end{tabular}

* B, before beta receptor blockade; A, af ter beta receptor blockade; $\Delta$, difference between A and B; Atr, after the intravenous injection of 2 mg atropine following propranolol administration; NS, not significant.

$\ddagger$ Average age is 32 yr (range $22-45$ yr). Average body surface area is $1.71 \mathrm{~m}^{2}$ (range $1.45-2.02 \mathrm{~m}^{2}$ ).
Age is $56 \mathrm{yr}$. Body surface area is $1.53 \mathrm{~m}^{2}$.

$2 \mathrm{mg}$ of intravenous atropine (18). This finding is consistent with the hypothesis that the prolongation accompanying alpha adrenergic and nonadrenergic vasoconstriction is dependent on reflexly induced vagal impulses to the heart.

The shift of the norepinephrine dose-response curve after propranolol (Fig. 6) demonstrates that it is possible to use beta adrenergic receptor blockade to detect beta adrenergic-mediated

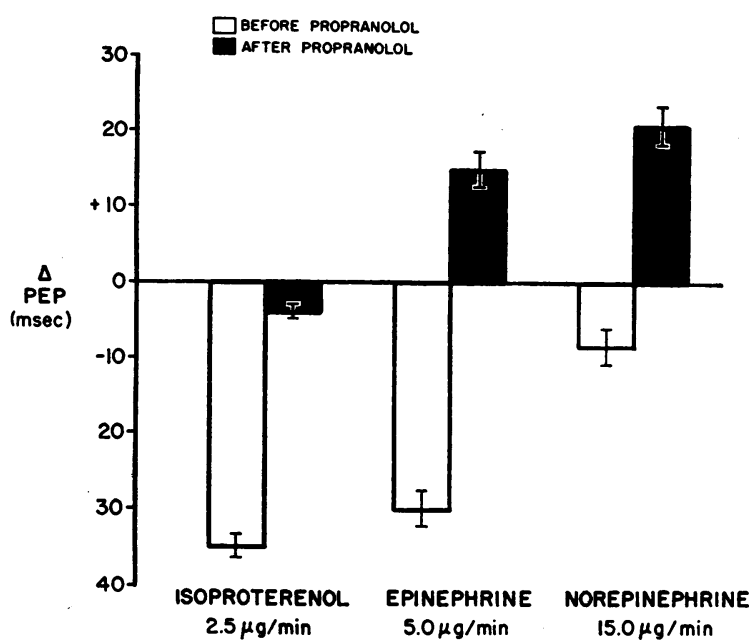

Fig. 5. Changes in the PREejection PERIOd PRoduced BY CATECHOLAMINE INFUSIONS. Isoproterenol was given intravenously to 25 normal subjects, epinephrine to 10 and norepinephrine to 15 . Each subject received the same agent before and after $10 \mathrm{mg}$ of intravenous propranolol. The bars represent mean changes from control ( $\pm \mathrm{SE}$ ) due to catecholamine infusion. The changes before propranolol are measured from control values before propranolol; those after propranolol from control values after propranolol. All changes from control shown are significant. shortening even in the presence of vasoconstriction-induced prolongation. The observed effect on the preejection period of a given dose of norepinephrine appears to depend on the relative proportion of beta adrenergic-mediated shortening and alpha adrenergic-related prolongation present. The findings in the present study suggest that the alpha adrenergic effect of norepinephrine is predominant at the lower doses while its beta adrenergic effect on the ventricle becomes increasingly prominent at the higher doses.

Stepwise increments in beta adrenergic receptor activation induced by isoproterenol shortened the preejection period in a dose-related manner. The amount of this shortening is therefore a function of the level of beta adrenergic activity. Increasing doses of propranolol shifted the isoproterenol dose-response curve to the right. The parallel na-

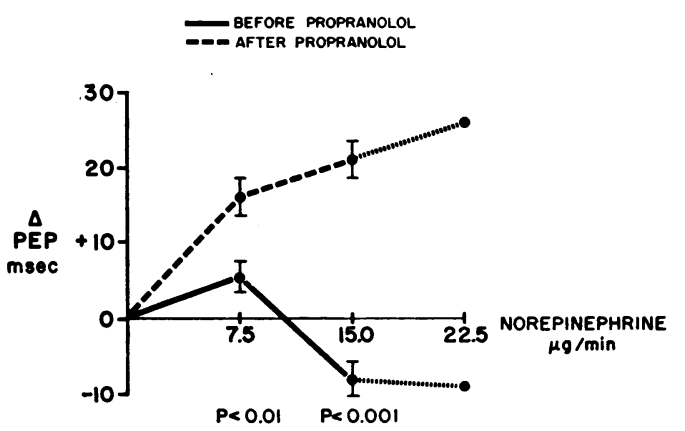

Fig. 6. EFFECTS OF GRADED INFUSIONS OF NOREPINEPHRINE ON PREEJECTION PERIOD IN 12 NORMAL SUBJECTS. Norepinephrine was given to each subject before and after intravenous propranolol $(10 \mathrm{mg})$. Three of these subjects received an additional dose of $22.5 \mu \mathrm{g} / \mathrm{min}$ (finely broken line). 
ture of these shifts resemble those observed in pharmacologic studies demonstrating competitive antagonism between two agents for the same receptor sites (19). However, because of many uncontrolled variables, it is emphasized that the present observations should not be interpreted as a rigorous demonstration of the type of blockade.

The results with cedilanid-D support the thesis that the ability of propranolol to prevent shortening of the preejection period is specific for beta adrenergic-mediated shortening. Cedilanid-D shortened the preejection period, reflecting its positive inotropic action on the myocardium. Propranolol did not block this non-beta adrenergic, digitalis-induced shortening. In preliminary studies in our laboratory, propranolol has also failed to inhibit shortening of the preejection period owing to thyrotoxicosis or to nonadrenergic reductions in peripheral resistance, such as occur with the opening of a systemic arteriovenous fistula or inhalation of amyl nitrite.

In normal resting subjects the intravenous infusion of $10 \mathrm{mg}$ of propranolol lengthened the preejection period an average of $10(\mathrm{SE} \pm 1) \mathrm{msec}$. The detection of excessive beta adrenergic influences on the left ventricle therefore requires that the prolongation by propranolol exceed this normal response. Although the finding of an effect in normal resting subjects is consistent with suppres-

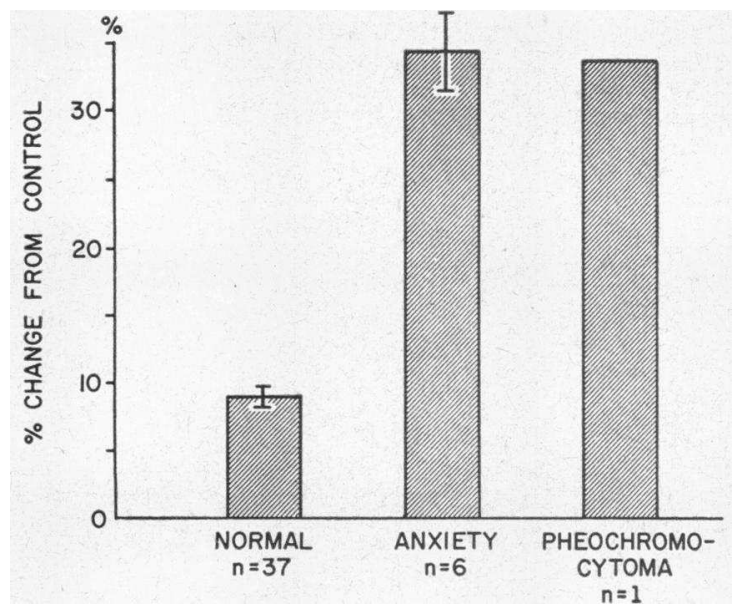

Fig. 7. EFFECTS OF BETA ADRENERGIC BLOCKADE ON PREEJECTION PERIOD. The patients with psychogenic tachycardia ("anxiety") and the patient with a pheochromocytoma tended to have short preejection periods, which beta receptor blockade lengthened by an amount greater than normal. sion of a basal level of beta adrenergic activity, the present data do not exclude an additional, possibly depressant, action of propranolol on the heart.

It is important to emphasize that nonadrenergic influences on the preejection period may either simulate or mask the presence of beta adrenergicmediated shortening. Low peripheral resistance, increased cardiac output, excess thyroid hormone, and positive inotropic agents, such as digitalis, may shorten the preejection period, while vasoconstriction may prolong it. For these reasons, the detection of excessive beta adrenergic influences on the ventricle cannot depend solely on the finding of a short preejection period but must include the demonstration of an abnormally great prolongation by specific beta adrenergic receptor blockade.

Two other possible determinants of the duration of the preejection period deserve mention: the level of left ventricular end-diastolic pressure and electrical-mechanical delay. Elevations in left ventricular end-diastolic pressure may occur during pharmacologic vasoconstriction in patients with normal left ventricular function (20) and at rest in some patients with congestive heart failure (21). A rise in left ventricular end-diastolic pressure, by diminishing the difference between itself and aortic diastolic pressure, might be expected to shorten the preejection period. However, both acute pharmacologic vasoconstriction, as shown here, and heart failure (22) in fact tend to prolong the preejection period, suggesting that other factors which favor prolongation, such as reflex mechanisms or a reduced rate of force development by the left ventricle, may dominate in these circumstances. Changes in left ventricular enddiastolic pressure are unlikely to contribute to the shortening effects observed with beta adrenergic receptor activation or digitalis administration, since these interventions do not raise end-diastolic pressure.

The role of electrical-mechanical delay in the effects of pharmacologic agents on the preejection period was investigated by determining the per cent of the preejection period response which occurred before and after the onset of the first heart sound. On the average, $74-81 \%$ of the shortening of the preejection period by isoproterenol, epinephrine, and cedilanid-D occurred after the onset of the first heart sound, and consequently during 
the isovolumic period of left ventricular contraction. The remainder of the shortening by these agents may be attributed to a reduction of electrical-mechanical delay, an abbreviation of the period from the onset of the left ventricular pressure rise to the first heart sound, or both. The prolongation of the preejection period induced by epinephrine after propranolol, norepinephrine after propranolol, and angiotensin occurred entirely after the onset of the first heart sound, and therefore exclusively during the isovolumic period of left ventricular contraction. Thus, changes in electrical-mechanical delay do not appear to have a major role in the effects of these agents on the preejection period.

The psychotic patients with sinus tachycardia (presumably due to chronic anxiety) and the patient with a pheochromocytoma had short preejection periods. Beta adrenergic blockade lengthened these by an amount clearly greater than normal (Fig. 7). This marked response of the preejection period suggests the presence of excessive beta adrenergic influences on the left ventricle, an impression consonant with the exaggerated bradycrotic effect of beta adrenergic receptor blockade in the same individuals. Restoration of the heart rate to prepropranolol levels by atropine did not reverse the effects of propranolol on the preejection period.

The preejection period can be measured easily and without trauma an unlimited number of times, making it well suited for repeated observations in man. Further studies applying the present approach may help in detecting abnormal states of cardiac sensitivity to adrenergic stimuli, in elucidating drug actions in man, and in delineating the role of autonomic influences in physiologic and disease states.

\section{Acknowledgments}

We are indebted to Dr. Richard $\mathrm{H}$. Brooks, Mr. Maury C. Koblentz, Commissioner of the Division of Correction, The Ohio Department of Mental Hygiene and Correction, and Warden Ernest L. Maxwell at the Ohio Penitentiary for their help in organizing this study. We gratefully acknowledge the invaluable technical assistance of Mr. Wayne Rose, Mr. David Meyer and Mrs. Virginia Schafer.

\section{References}

1. Raab, W., P. DePaula e Silva, and Y. K. Starcheska. 1958. Adrenergic and cholinergic influences on the dynamic cycle of the normal human heart. Cardiologia. $33: 350$.

2. Rushmer, R. F. 1962. Effects of nerve stimulation and hormones on the heart; the role of the heart in general circulatory regulation. In Handbook of Physiology. Section 2: Circulation. W. F. Hamilton and P. Dow, editors. American Physiological Society, Washington, D. C. 1 : 533.

3. Wallace, A. G., J. H. Mitchell, N. S. Skinner, and S. J. Sarnoff. 1963. Duration of the phases of left ventricular systole. Circulation Res. 12: 611.

4. Glick, G., E. H. Sonnenblick, and E. Braunwald. 1965. Myocardial force-velocity relations studied in intact unanesthetized man. J. Clin. Invest. $44: 978$.

5. Moran, N. C., and M. E. Perkins. 1958. Adrenergic blockade of the mammalian heart by a dichloro analogue of isoproterenol. J. Pharmacol. Exp. Therap. $124: 223$.

6. Shanks, R. G. 1966. The effect of propranolol on the cardiovascular responses to isoprenaline, adrenaline and noradrenaline in the anaesthetized dog. Brit. J. Pharmacol. $26: 322$.

7. Black, J. W., A. F. Crowther, R. G. Shanks, L. H. Smith, and A. C. Dornhorst. 1964. A new adrenergic beta-receptor antagonist. Lancet. 1: 1080.

8. Kimball, J. T., and T. Killip. 1965. A simple bedside method for transvenous intracardiac pacing. Am. Heart J. 70: 35.

9. Cullumbine, H. 1965. Cholinergic blocking drugs. In Drill's Pharmacology in Medicine. J. R. DiPalma, editor. McGraw-Hill Book Co., New York. 3rd edition. 450.

10. Spann, J. F., Jr., E. H. Sonnenblick, T. Cooper, C. A. Chidsey, V. L. Willman, and E. Braunwald. 1966. Studies on digitalis. XIV. Influence of cardiac norepinephrine stores on the response of isolated heart muscle to digitalis. Circulation Res. 19: 326.

11. Snedecor, G. W. 1956. Statistical Methods Applied to Experiments in Agriculture and Biology. Iowa State College Press, Ames, Iowa. 5th edition.

12. Harris, W. S., C. D. Schoenfeld, R. H. Brooks, and A. M. Weissler. 1966. Effect of beta adrenergic blockade on the hemodynamic responses to epinephrine in man. Am. J. Cardiol. 17: 484.

13. Reeves, T. J., L. L. Hefner, W. B. Jones, C. Coghlan, G. Prieto, and J. Carroll. 1960. The hemodynamic determinants of the rate of change in pressure in the left ventricle during isometric contraction. Am. Heart J. $60: 745$.

14. Van Bogaert, A. 1966. New concept on the mechanism of the first heart sound. Am. J. Cardiol. 18: 253.

15. Dale, H. H. 1906. On some physiological actions of ergot. J. Physiol. (London). 34: 163.

16. Ahlquist, R. P. 1948. A study of the adrenotropic receptors. Am. J. Physiol. $153: 586$. 
17. Goldenberg, M., K. L. Pines, E. de F. Baldwin, D. G. Greene, and C. E. Roh. 1948. The hemodynamic response of man to nor-epinephrine and epinephrine and its relation to the problem of hypertension. Am. J. Med. 5 : 792.

18. Harris, W. S., A. M. Weissler, and R. H. Brooks. 1966. Vagal influences on left ventricular contraction in man: A cause for prolongation of the pre-ejection period. Clin. Res. 14: 426. (Abstr.)

19. Ariens, E. J., A. M. Simonis, and J. M. van Rossum. 1964. Drug-receptor interaction: Interaction of one or more drugs with one receptor system. In Molecular Pharmacology. E. J. Ariens, editor. Academic Press Inc., New York 1: 149-153.
20. Ross, J., Jr., and E. Braunwald. 1964. The study of left ventricular function in man by increasing resistance to ventricular ejection with angiotensin. Circulation. 29 : 739.

21. Ross, J., Jr., and E. Braunwald. 1964. Studies on Starling's law of the heart. IX. The effects of impeding venous return on performance of the normal and failing human left ventricle. Circulation. $30: 719$.

22. Weissler, A. M., W. S. Harris, C. D. Schoenfeld, and J. V. Warren. 1966. Effects of heart failure on systolic time intervals in man. Circulation. 34 : III-236. (Abstr.) 